\title{
Urban Devastation: the Case Study of Podgorica, the Capital of Montenegro
}

\author{
Dragan Komatina, University of Montenegro \\ Saja Kosanović, Julija Aleksić, University of Priština
}

\begin{abstract}
The subject of the research is manifestation of urban space devastation in Podgorica through monitoring and influences which cause it. Theoretically, the paper represents a wider study of devastation genesis as an occurrence which negatively affects the urban concept of the city. Apart from the study of reasons and conditions which lead to urban space devastation, a particular significance of this research lies in the suggested mechanisms for the resolving of detected irregularities. The primary significance of the identification of devastation and its participants represents the achievement of the goal to offer effective and practical concept that should assist in preventing further urban space devastation, both in Podgorica and urban areas in general.
\end{abstract}

Keywords - Urbanization, devastation of space, urban planning; devastation of space in Podgorica, illegal construction.

\section{INTRODUCTION}

The subject of the research is manifestation of urban space devastation, through monitoring of the manifestation itself and its causes in Podgorica. Theoretically, the paper represents a wider study of devastation genesis, as an occurrence which negatively affects the urban concept of the city [2]-[6]. The results of urban devastation are not only a local problem of visual and technical nature, they also convert into the insecurity factor, which causes slower investment inflow, both local and foreign (from highly developed countries), which is one of the requirements for economic and cultural growth in the future.

Apart from the study of reasons and conditions which lead to urban space devastation through the analysis of planning and administration documentation as well as the overview of terrain analysis and their implementation, a particular significance of this research lies in the suggested mechanisms for resolving of the detected irregularities. Of course, the primary significance of the identification of devastation and its participants represents achievement of the goal which alludes to the offering of effective and practical concept that should assist in preventing further urban space devastation, both in Podgorica and urban areas in general. Apart from urban planning, devastation is also present as a feature of architectural facilities, but this paper will not address any of them.

\section{Definition of the Term}

"Devastation" is an internationally known term from new Latin devastare, mostly used when speaking of devastation, destruction, desolation.
The manifestation of spatial devastation is connected with human involvement in its planning and creating. There are multiple terms and expressions that are used for spatial devastation through urban and construction development. "Illegal construction", "wild construction", "grey", unplanned construction are synonyms for the same occurrence which refer to spatial devastation through urban construction, emerged from the construction beyond legal and professional regulations, and they are highly used by both professional community and generally.

Urban planning of space, as well as its construction disregarding legal regulations, standards, planning and designing ethics represents direct devastation of urban and construction entireties of a certain space, i.e. spatial devastation.

\section{Devastation of Podgorica Through Urban Development}

Montenegro is located in the Western part of Balkan Peninsula, with an area of only $13,812 \mathrm{~km}^{2}$ and population of 620,029 according to the last census in 2011. In such small territory, it is natural that occurrences tend to repeat themselves, due to the vicinity of its territorial entireties and small-town-mentality which is present in the whole country. Therefore, the same formula can be applied to the appearance of construction and urban space devastation. Particularly, Podgorica as the capital of Montenegro represents a research example of spatial devastation reflecting in all twenty-two municipalities of the country.

The best way to understand a city's development and genesis is by reviewing its temporal continuity as well as its changes and transformations. All social-economic on-goings, territorial, cultural and other interests during history have resulted in constant alternation of construction and demolition - destruction periods, which form a closed timeline without the end and the beginning, following the development of a human as the main creator of that sequence.

\section{A. Urban Legacy}

"If we leave spatial solutions of Roman town Duklja, medieval town Nemanja and Stara varoš from Turkish period in the past, in full awareness that their urban concepts and trends of development portray the typicality of given times, we are reaching the time period which can rightfully be considered as the proper base for this study" [7].

The first urban plan of Podgorica after liberation from Turks in 1879 , initiated by engineer Vorman, had the features of neo- 


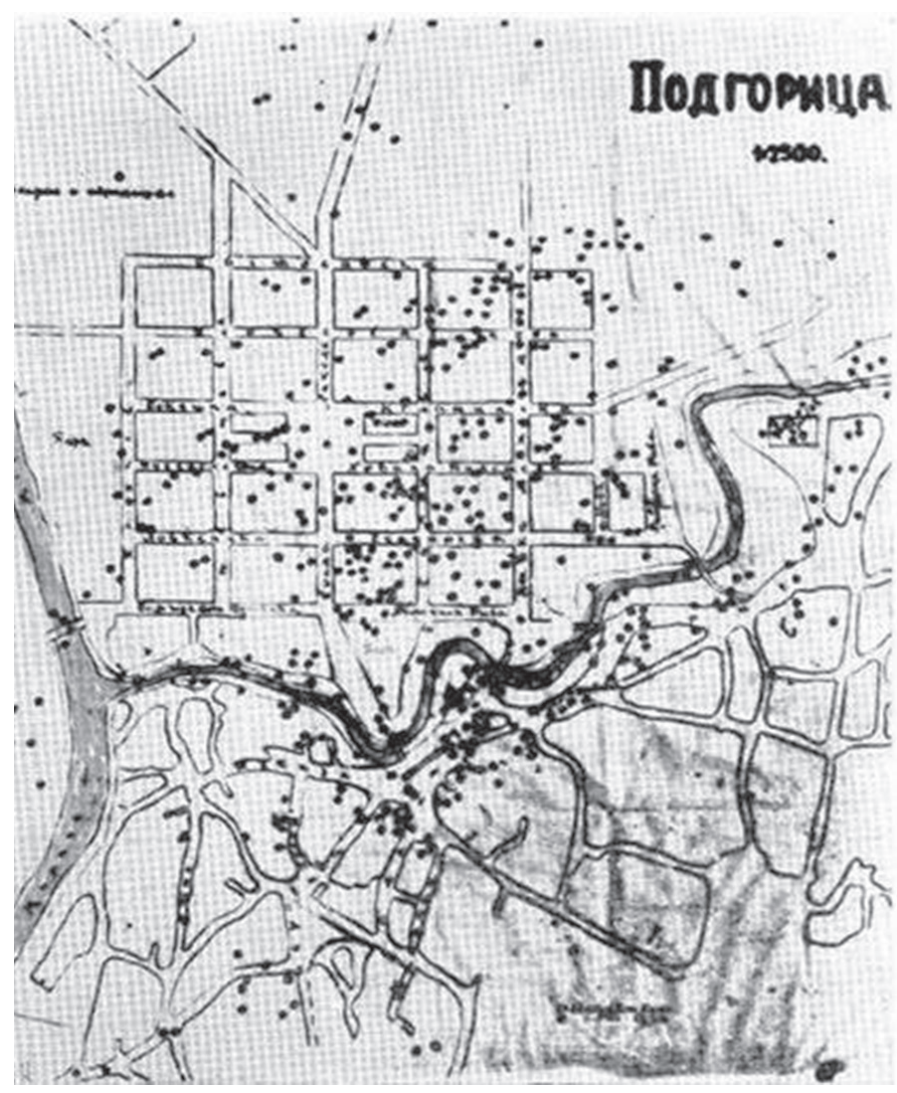

Fig. 1. Alliance bombing map of Podgorica in 1940, showing Vorman's orthogonal organization of the Ribnica right bank and free organization of Stara Varoš on the Ribnica left bank. Reference [7].

classical town model. According to that plan, Podgorica was conceived as an orthogonal matrix with block structure which was allowed by flat terrain (block dimensions $100 \times 100 \mathrm{~m}$ ) on the right bank of the Ribnica river (Nova varoš nowadays). A quadrangular square was located centrally in orthogonal matrix. Seven parallel streets poured into the square from the East and West, while they intersected with four streets and one central (which cut the square in the middle and spread towards Stara varoš) from the North and South. Nova varoš was planned mostly as G+1.

During World War I, Podgorica did not suffer any major destruction and its growth was continuous up until World War II. Being a regional and commercial centre, Podgorica became a place of massive construction, and the financial interests caused changes to Vorman's plan mostly in terms of number of floors of buildings (which increased up to $\mathrm{G}+3$ ). This has led to the violation of elevation balance initially set by Vorman's plan.

During World War II, the development of Podgorica stopped completely. During the war, it was bombarded 66 times and was entirely demolished (Fig. 1) [7].

The replacement of an early undeveloped capitalist social order with new, communist-socialist order, began a new chapter for the demolished Podgorica. In 1946, its name was changed to Titograd and it became the capital of the People's Republic of Montenegro. The new communist government immediately initiated the

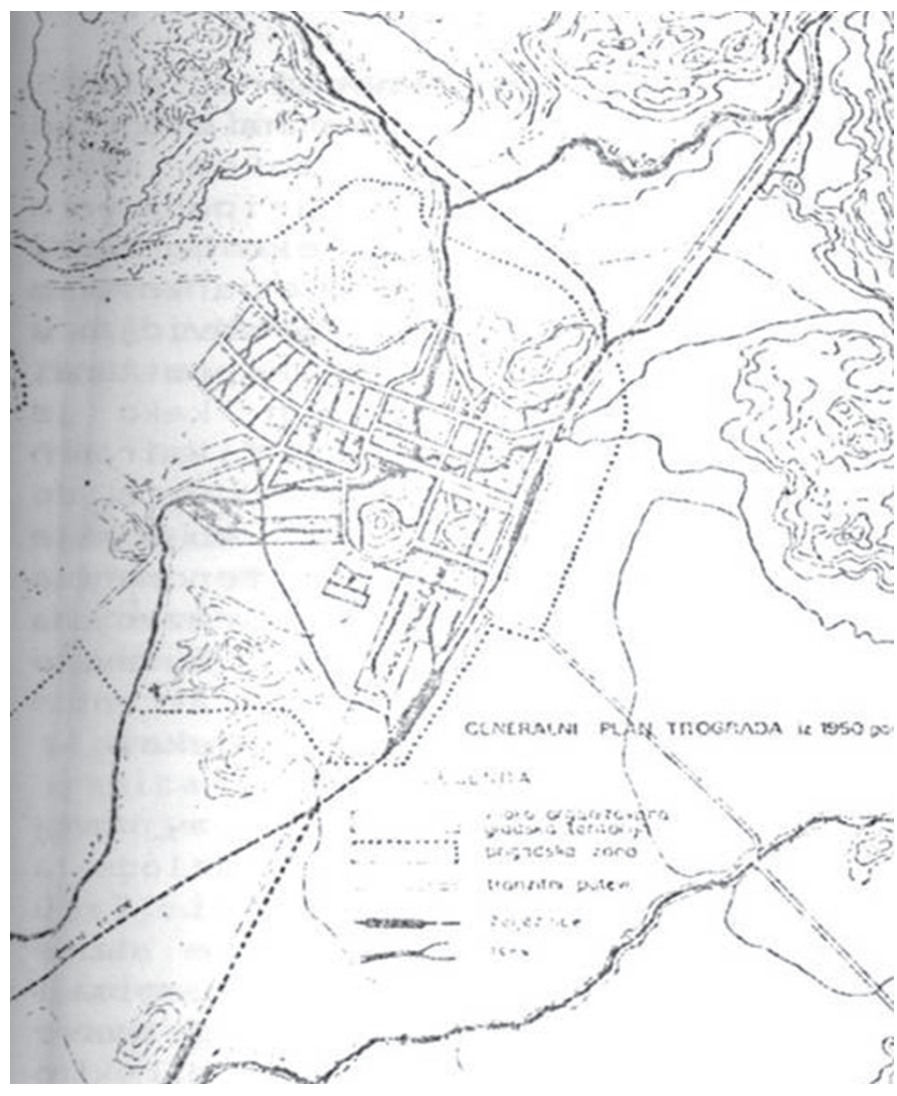

Fig. 2. Spatial Plan of Titograd in 1950 [2]

elaboration of The General Plan. Basically, the Plan followed the primary concept of Vorman's orthogonal spatial organization, which was supplemented with facilities which had to be present in Titograd as the capital. The Plan envisaged that the railroad through the town should be located in its Western part. In 1948, the Ministry of Traffic, without any planning consultancy and disregarding the initial concept, relocated the railroad route to the Eastern part, which caused a deadlock regarding the elaboration plan. By doing this, the government affected the town development through political decisions. These negative occurrences took place also in years to come, becoming the main reason of constant struggle between the professionals and politicians.

After the first concept of urban development failed, the elaboration of the new General Plan of Titograd was initiated in 1948, and was adopted in 1950 (Fig. 2) [2]. The town developed to the West from the new railroad route which transferred the Vorman's orthogonality to Nova varoš on the right bank of the Morača river. However, the plan was full of pre-monumental urban zones, which could not be completed due to the economic weakness of post-war Montenegro.

The elaboration of the new General Plan started in 1954 and ended in 1957 (Fig. 3) [2]. The plan included the town development until 1975, when it was envisaged that Titograd would have 45000 inhabitants. The accent of the town development was put 


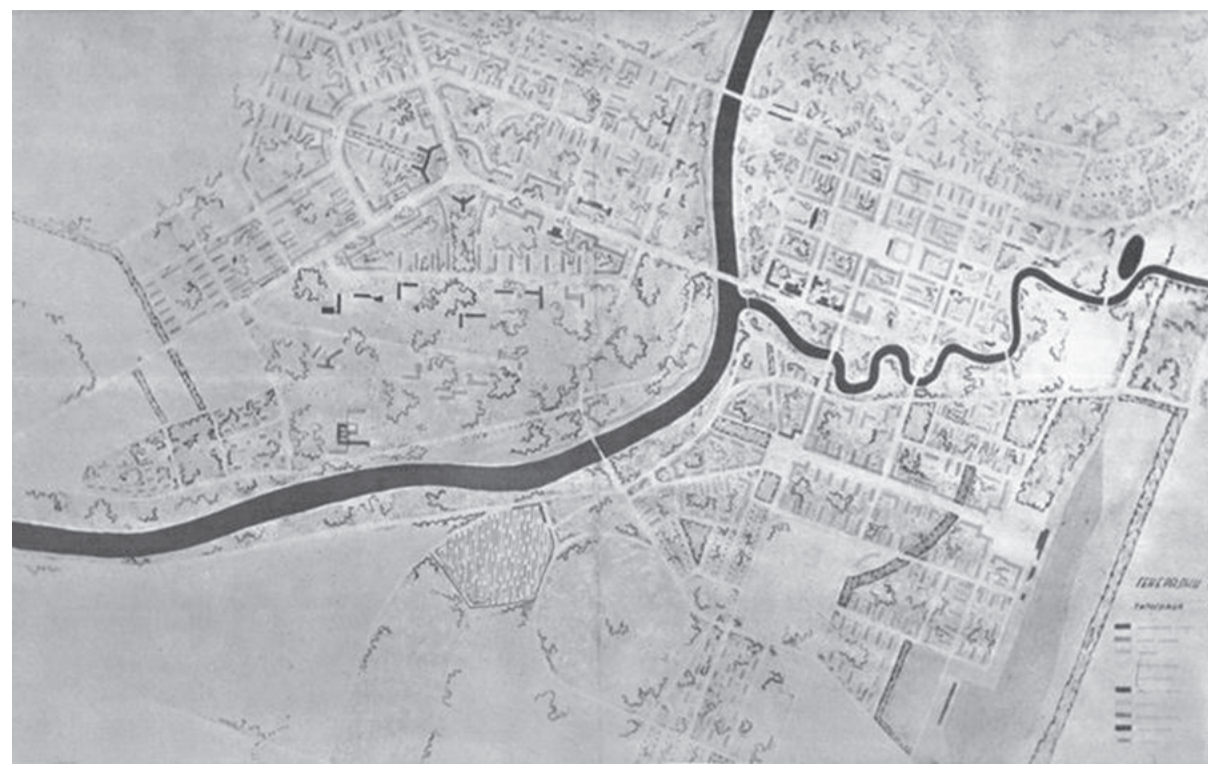

Fig. 3. Spatial Plan of Titograd in 1957 [2].



Fig. 4. Spatial Plan of Titograd in 1964 [2]. on the right bank of the Morača river, to which orthogonal structure of Nova varoš was transmitted. The problem of devastation which emerged due to discrepancies in construction speed and planning on one hand, and deeper analysis of planned area on the other hand, turned the government into the main illegal builder.

Centralization of Montenegro towards Titograd and its intense construction, followed by large inflow of new population surpassed the envisaged planning estimations of spatial and demographic town development. This imposed the need for the revision of the Plan which started in 1961, and ended in 1964 when it was adopted (Fig. 4). The main feature of the Plan was the clear definition of basic spatial functions: work, habitation, leisure, recreation and similar functions. The literal application of functionalistic doctrine by Le Corbusier was the cause why this Plan envisaged using of large elements of wide traffic zones and spacious green areas within blocks of public space. Conceptually-wise, the plan relied on the principles of The Athens Charter of 1933. Good traffic organization specified the place, size and appearance of buildings. Blocks with the dimensions of $100 \times 100$ metres, which were completely closed by buildings, resulted in narrowness of the town development, therefore, according to the needs of a modern inhabitant, they were replaced by blocks of $300 \times 400$ metres in orthogonal system, and strong traffic roads and wide street profiles kept the pedestrians further away from the road, and the tenants away from the street noise. Although it had quality, this plan, also suffered from devastation attacks. They, mostly, took place due to lack of funding which usually follows the completion of an ambitiously set plan, which instead of the concentration of construction caused the cession of vacant or completely available locations for construction of individual buildings, scattered all over the town territory.

The manner of the completion of the plan during the $60 \mathrm{~s}$ and $70 \mathrm{~s}$, as well as the doctrine ruling among the planners of Titograd (implying the consideration of plans, political support and sustainability, constant valuation, as well as time to time examination) led to the revision of the new Plan in 1974 (Fig. 5) [2]. This revision involved economic progress up to 1991, and in terms of space, a long-term plan reflection. However, the issues with hardly predictable migration logic, especially immigration, are still markedly present. The state as the main builder still happened to be the largest violator of the Plan's regulations. It was especially visible in industrial zones.

\section{B. Actual Urbanization}

In 1987, the team of experts from Slovenia was entrusted with the repeated revision of The General Plan of the town (Fig. 6) [2]. Obvious issues of illegal construction and the extent of devastated space by individual construction were documented in the new Plan, but it was not completely successfully accomplished regarding the provision of guidelines for its solution.

The civil war and destruction following the disintegration of the Socialist Federal Republic of Yugoslavia from 1989 to 1998 opened the path to various factors and forms of degradation and space devastation. Among particular degradation and space devastation factors in this time period, the following ones were clearly distinguished:

- weakening of state functions, which was mostly conditioned by the chaotic state due to political, social and economic dissent within the great Yugoslavia;

- economic difficulties emerging due to war destruction on one hand, and strong international economic and all other possible sanctions towards Yugoslavia, on the other hand;

- rapid increase of poverty as a consequence of living and working in war-enveloped surroundings;

- $\quad$ large shift and migration of general population in wider territory due to war effects; 

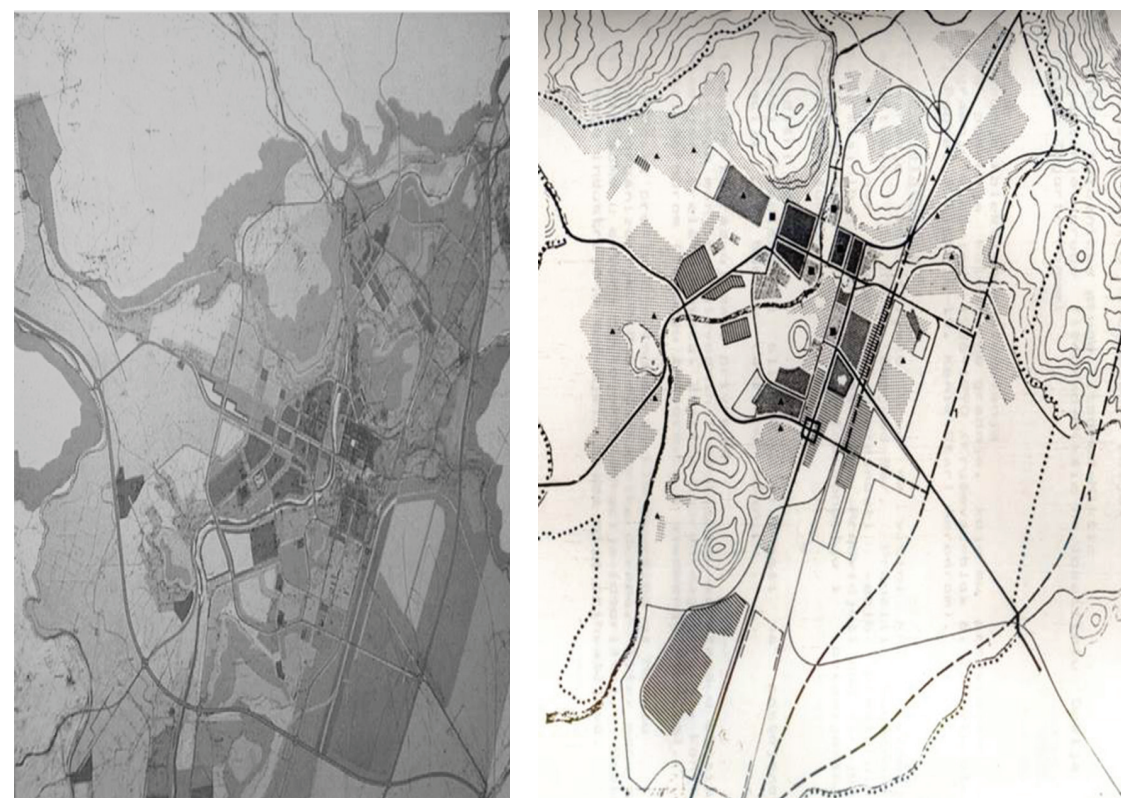

Fig. 5. Spatial Plan of Titograd in 1974 [2].
Fig. 6. Spatial plan of Titograd in 1987 [2].

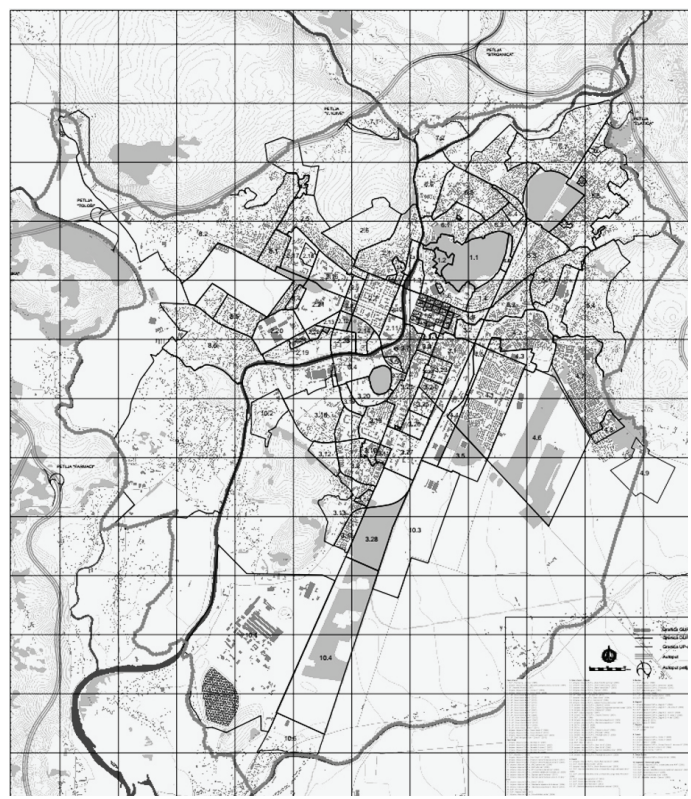

Fig. 7. Spatial plan of Podgorica in 2013 [3].
- collapse of earlier social-economic planning model and non-existence of the new system and model of the planning process during the time of transition;

- $\quad$ privatization, free market, enormous strengthening of private interests;

- $\quad$ unclearly defined public interests;

- $\quad$ perforated limits and ranges of spatial planning possibilities and disrupted sustainable development indicators;

- non-existence of intense planning activity both at national and local level;

- derogation from previously issued planning documents;

- takeover of the elaboration processes of plan from the State Planning Institute by private planning and designing companies.

The following forms of space devastation were characteristic in this time period:

- Devastation of national and general social assets, which, due to weakness of state care and control mechanisms became the subject of theft in private and local interest. Poverty and complicated procedure of obtaining a building permit to construct one's own roof over the head were the starting point of construction of illegal residential buildings. Low level of democratic models regarding manners of attracting the voters caused the silent approval of the attacks by possible voters on state property. Such generally accepted mass crime was covered by the mantle of "social caring" and "building the roof over one's head", as a model of existential necessity.

- Devastation of locations in private property emerged due to non-existence or disregard of existing planning documentation. In this case, understanding of private property which was emphasized by the renewed capital- ist value system was used in an entirely wrong way. An individual, as the owner, provided himself with the right to specify and decide on the content, the type of the building and the number of floors to be constructed on his parcel, while neglecting collective interests. An individual did not want or could not comprehend that the Plan did not deny his right to the property and the Plan and the space were a collective asset of all citizens;

- Devastation in areas not included in planning documentation. Illegal and uncoordinated construction was a major issue in these areas. The country, due to its state and large population inflow, identified these cases, but besides the fact that it did not protect its property legally, it even put the usurpation issue under the frame of social policy;

- Devastation of areas inhabited by mono-ethnic minority communities. It emerged due to the same or similar reasons already listed above, along with the feature that these were the areas where ethnic minorities lived (the area of Tuzi and Malesija). Each attempt to prevent and control the construction made by institutions was politicized and condemned to defeat at the very start.

- Devastation of areas due to the aim of earning extra-profit. The lack of permanent planning and staff which would exclusively take care of the developing processes allowed the private financial lobbies to become a relevant factor in creation and spatial construction. The municipality and the government, due to lack of funding for normal functioning, made exceptions which led to the worst form of spatial devastation leading to collapsing of locations both in horizontal and vertical dimensions. Such irresponsible destruction was caused by the profession of planning and designing, which was one of the main 
"masterminds". The only link in this chain that respects the value of the space is financial lobby or the individual, but, unfortunately, they observe it only through the prism of extra-profit earning.

On 21 May 2006, Montenegro became an independent and internationally recognized state. The attractiveness of Montenegro as a tourist destination opened the possibilities of the inflow of direct foreign investment. However, neither Montenegro nor Podgorica were ready to channel in a reasonable manner large amounts of capital, which poured into the state via individuals and funds from abroad. Explosion of construction in unbelievable proportions took place in entire country. Due to previous practice and long and painful transition period, the planning documentation was either not ready or was surpassed. The fast remediation model of existing buildings was used, which partially fulfilled the wishes of new investors. Therefore, earlier planned and systematically studied infrastructure was disrupted, which led to problems in water supply, sewage and storm sewage, electrical and traffic infrastructure. One of the main forms of funding was selling of town locations as well as charging utility taxes. Due to such trend of investment into construction, which became the only production area, the number of residential units in Podgorica rapidly grew in regard to the number of inhabitants. In August 2008, the new Law on Construction and Planning of Buildings was issued as a reaction to current state and an attempt to resolve the documented problems in construction. The basic innovation in the Law was the articles which refer to all illegal actions in the process of building construction and spatial devastation, and for the first time, these actions were qualified as felonies by a certain legislative act. The penalty prescribed for this type of violation was imprisonment of up to five years. However, this was also the time when economic crisis took place not only in Montenegro but also in the whole world. One of the consequences was the stagnation in construction, which had lasted up to nowadays. Nevertheless, Podgorica has used the stagnation for elaboration of the new Spatial plan, which was adopted in 2013 (Fig. 7) [3].

\section{Future Development}

After issuing of the Spatial Plan of the Municipality, the town of Podgorica needs to continue its detailed elaboration, through developing detailed plans for individual zones. Particularly, the attention should be paid to solving and implementation of rapid and modern traffic that ensures the basic elements of organizational and spatial town development and to take into consideration the suggestions of planners in the sixties and seventies of the twentieth century. There were predictions that Podgorica, as a capital, will connect with Danilovgrad Municipality temporarilly and spatially to the West. Podgorica is expanding both towards the South and Zeta Plain, as well as towards township Golubovci with 30000 inhabitants. On the Eastern side Podgorica has a great potential for expanding and construction at Ćemovsko polje, towards the Cijevna river and township Tuzi. Endless vineyards of "Plantaže" company form a large positive dam and future development and protection regulator of this area in terms of overcrowding and construction. "Cardboard settlements" of socially endangered population categories also participate in violation of space and image of each modern city. Even though certain effort was made in terms of taking care and involvement of these people into normal urban life, in future this issue must be treated with greater attention, and through care of such groups in collective inhabitation.

\section{Systematic Approach and Methodology for} the Resolution of Space Devastation Problem

Urban issues present in the development of Podgorica, as well as various social frames in which they emerge, lead us to the final aim, i.e. defining the measures and mechanisms that can help to remove these causes.

1) Legal-administrative cause. This aspect is directly connected to executive and administrative authorities and their ineffectiveness, through corruption and professional incompetence to protect and create space, which lie in the basis of all other irregularities and demand wide and serious engagement of entire society, starting with the highest state bodies. That is why it is necessary to set up a sound system of spatial planning in accordance with the accomplishments of countries which regulated that area. In order to remove this most relevant set of issues, it is necessary to implement a complete package of the following measures:

- $\quad$ Promulgation of clear law regulations in the planning process, would have to offer organizational and temporal frames for solving issues caused by lack of valid planning documentation, as well as define deadlines for elaboration and renewal of plans. When issuing decisions on plan elaboration, each step of the process up to its entry into force must be realistically predicted and limited. That would stop the current temporarily long and without deadlines and limitations elaboration process of the plan. Apart from respecting the temporal deadlines, it is necessary to determine legal requirements regarding the planning of houses and awareness of problems of the concerned area, as well as to respect the strategic evaluation of influences of ecologic plan. Prior to the beginning of the elaboration of the planning document, sanctions for the breach of the procedure in its elaboration and promulgation should be envisaged for all participants (bodies that issue the decision, timely provide all necessary basis and announce the contest for plan elaboration, elaborator, revision and public enterprises which provide approvals of the draft plan and the ministry which performs the audit on the compliance with proposals and higher plans). The Law on Planning and Spatial Arrangement, The Law on Construction of Structures and The Law on the Construction Land must be in mutual correspondence along with necessary institutional support and adequate resources for their application. A separate law concerning consequences of illegal construction and space devastation in general would create a much more serious foundation for the resolution of this problem. 
- Adoption of bylaws/subordinate legislation which would simplify and temporarily limit the process from the submitting of the application to issuance of construction permit from 30 days to 60 days. Such actions would assist to terminate the existence of the administration silence system, as well as define legal sanctions for the administration inefficiency.

- Development of clear guidelines on the procedure of the construction process, which would provide inspection bodies with the instructions for permanent, quality and non-selective monitoring.

- Education of the staff involved in the development, application and control of the planning and construction process. Sanctioning of corruption and incompetence in administrative bodies, by measures adequate for such misdemeanour, from the loss of professional authorities to processing of criminal charges. It would be possible to decrease corruption by increasing personal income of the officers in accordance with their authority as well as through intense internal control. It is also necessary to provide the control by the resource ministry which would monitor the work of the inspection and administrative services at the level of municipalities.

- It is possible to stop the connection between corrupted administration and strong financial lobbies only through serious and non-selective application of legal penalties envisaged for the abuse of the official position at all levels of administration starting from the top.

2) Legal-political causes, which reflect through the silent approval of urban space devastation by political structures with the goal to win political points providing longer time in power. Space usurpations and degradations must be stopped through complete de-politicization of the space management system. It means that political structures, in the struggle for winning and keeping power, must renounce this field while gathering political points. Political responsibility will be shown by those politicians who evict themselves from this process, because the spatial planning is the most obvious indicator of the level of country's development as well as of the devotion of governing structures to general and not private interests and the capacity to manage the territory of the country. Elaboration of quality development strategy of municipalities at the level of five-year or one-year planning programs and spatial arrangement by professionals not by political campaigns, and its consistent implementation by competent municipal services would prevent many of the specified problems. The decisions regarding managers in urban-architectural profession must be made in professional organizations. Induction of the anonymous public contest (obligation) for all public structures and arrangement of public areas would also alienate elements of daily politics from the designing.

3) Social-economic causes. We distinguish two urban space devastation causes according to social differences of the participants as their carriers:

- The first group of participants is represented by people belonging to socially endangered categories. Social policy should be used for planning the construction of residential buildings for social needs and coordinated obtaining of funds from the budget, donors and by participation of domestic and foreign non-government organizations.

- The second group of participants is represented by individuals or groups of strong financial lobbies which, due to earning profit, perform the urbanization and construction disregarding the regulations of spatial planning. Precise legal regulations should define the responsibilities within the planning process, which would include administration, investors and planners.

4) Scientific-professional causes of spatial devastation should be eliminated at two levels. Apart from criminal sanctioning, competent persons in any way participating in the space devastation process must be condemned by professional community and penalized by losing the authority to work in the field in which legal and professional rules have been violated.

Incompetence and insufficient knowledge of contemporary trends in planning should be systematically solved by organizing professional counselling by staff education abroad and training in advanced and scientific studies.

5) Cultural causes, such as lack of education and lack of urban culture must be gradually eliminated by introducing wide social activities with the aim of raising awareness of the rules of urban living, as well as sanctioning measures of actions that violate such rules.

\section{Conclusion}

It is clear that urban space devastation is typical for each human settlement and is a product of human activities. However, the regulations and control of space planning is a necessity and demand clear, precise and unambiguous steps and instructions. Separation of professional planning approach from the influences of the governing system and political influences is the priority which each profession must deal with, through introducing the control of legal models and work procedures and their implementation in the planning process and its completion. Struggle in life is something that we, as human beings, face on everyday basis and it must be present in space preservation too, which is decreasing with each day due to increase of population on Earth. Limitation of the country area, as well as its resources on one side, and population growth on the other side, impose an obligation that we, as experts, have no right to make mistakes both in planning and space construction.

\section{REFERENCES}

1. Gruber, M. Urban disorder and protection of order. Belgrade: Architecture, Nr. 135, March 2009. p. 12-13.

2. Spatial plan of Titograd municipality, Plan Draft, Planning Institute of The Socialist Republic of Slovenia, Titograd, 1987.

3. Spatial urban plan of the capital podgorica until 2025, Plan Draft, Urbi Montenegro, Podgorica (lic. no 1201-442/1) - Planning Institute of The Socialist Republic of Slovenia, Podgorica, 2013. 
4. Report on progress of planning spatial planning and implementation plans for the year 2010, Department for Urban Planning and Construction of the Municipality of Podgorica, Podgorica, 2011.

5. Report on progress of planning spatial planning and implementation plans for the year 2011, Department for Urban Planning and Construction of the Municipality of Podgorica, Podgorica, 2012

6. Report on progress of planning spatial planning and implementation plans for the year 2012, Department for Urban Planning and Construction of the Municipality of Podgorica, Podgorica, 2013.

7. Knezevic, V. Protection of cultural monuments and heritage : studu. Muzej i galerije Titograda, Titograd, 1987.

8. Stošić, Lj. Strategic planning in local autorities. International scientific-professional meeting, Summer school of urbanism, Kladovo, Serbia, 2011. p. 163-168.

9. Milić, V. From legalization to reconstruction. Dans, No. 43, Novi Sad, September, 2003. p. 21-23.

10. Tomašević-Zlatanović, V. Spatial and urban planning and legalization International scientific-professional meeting, Summer school of urbanism Kladovo, Serbia 2011, p. 25-30.

11. Davis, M. Planet of slums. London: Verso, 2007. 256 p. ISBN 978-1844671601

12. Spatial planning - key instruments for development and effective goverance with special reference to countries in transitions [online]. UNECE [cited 1.09.2015]. https://www.unece.org/hlm/publications_recent10.html

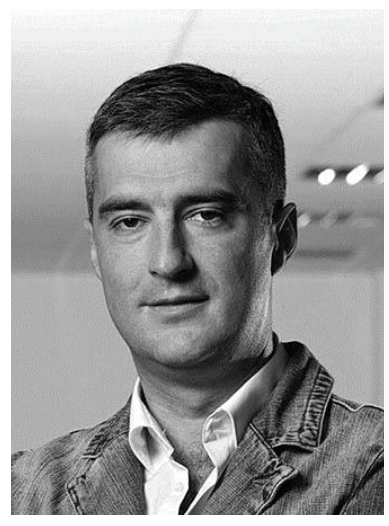

Dragan Komatina obtained the $\mathrm{PhD}$ degree from the Faculty of Civil Engineering, Department of Architecture in Podgorica in 2010, the M. Sci. degree in Architecture and Urbanism from the Faculty of Architecture in Belgrade in 2003, and the M. Arch. degree from the Faculty of Architecture and Civil Engineering in Priština in 1997.

He is an Assistant Professor with the Faculty of Architecture of University of Montenegro in Podgorica. He lectures on architectural analysis, architectural and computer graphics, residential buildings, health facilities and architectural details. He is also tutors design studio work. His research field is architectural design. He is a practicing architect in his own design bureau Studio K in Podgorica:. He has received awards and several international architectural-urban prizes.

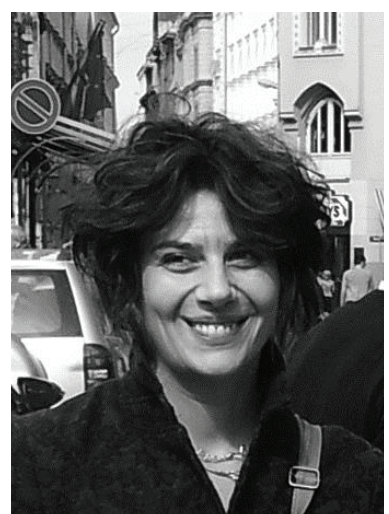

Saja Kosanović obtained the $\mathrm{PhD}$ in $\mathrm{Ar}-$ chitecture and Urbanism from the Faculty of Architecture in Belgrade in 2012, the M. Sci. degree in Architecture and Urbanism from the Faculty of Architecture in Belgrade in 2007, and the M. Arch. degree from the Faculty of Architecture and Civil Engineering of University of Priština in 2000 .

She is an Assistant Professor with the Department of Architecture of Faculty of Technical Sciences of University in Priština. She is a Visiting Professor with the Faculty of Architecture in Belgrade and lectures in architectural design, sustainable architecture and urbanism, environmental assessment of buildings, and tutors design studio work. She is the author of the National system for environmental assessment of single-family houses and of the book Environmentally Friendly Buildings -
Introduction to Planning and Design. Her main research interests are architectural design, environmental impacts of buildings, sustainability assessment methodologies, sustainable architectural and urban strategies, planning and design, architectural education. She is a practicing architect. She is a member of editorial and scientific boards of several journals and scientific conferences.

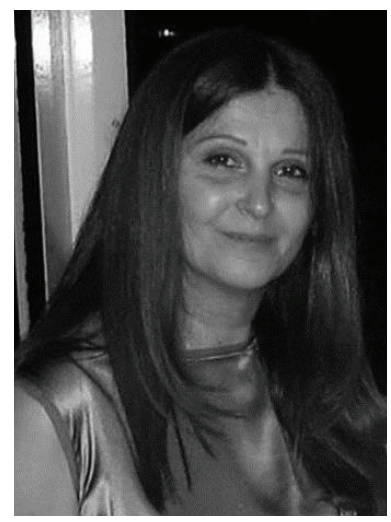

Julija Aleksić received the M. Sci. degree in Architecture and Urbanism from the Faculty of Architecture in Belgrade in 2010, and the M. Arch degree from the Faculty of Architecture and Civil Engineering of University of Priština in 1988. Presently she is finishing her $\mathrm{PhD}$ thesis with the Faculty of Architecture and Civil Engineering in Banja Luka.

She is an Assistant Professor with the Department of Architecture of Faculty of Technical Sciences of University of Priština. She is running classes in architectural design, including studio work. Her research areas are mobile and prefabricated architecture. She is a practicing architect, interior and fashion designer.

\section{Contact Data}

Dragan Komatina

E-mail: komatinadragan@gmail.com

Saja Kosanović

E-mail: saja.kosanovic@pr.ac.rs

Julija Aleksić

E-mail: julija.aleksic@pr.ac.rs 